Cahiers $d u$ MONDE RUSSE

\section{Cahiers du monde russe}

Russie - Empire russe - Union soviétique et États indépendants

$58 / 4 \mid 2017$

Varia

\title{
Steven Sabol, The Touch of Civilization: Comparing American and Russian Internal Colonization
}

\section{Alexander Morrison}

\section{(2penEdition}

\section{Journals}

Electronic version

URL: http://journals.openedition.org/monderusse/10142

DOI: $10.4000 /$ monderusse. 10142

ISSN: $1777-5388$

\section{Publisher}

Éditions de l'EHESS

\section{Printed version}

Date of publication: 1 October 2017

Number of pages: $672-674$

ISBN: 978-2-7132-2698-4

ISSN: $1252-6576$

Electronic reference

Alexander Morrison, "Steven Sabol, The Touch of Civilization: Comparing American and Russian Internal Colonization", Cahiers du monde russe [Online], 58/4 | 2017, Online since 01 October 2017, connection on 05 January 2021. URL: http://journals.openedition.org/monderusse/10142 ; DOI: https://doi.org/10.4000/monderusse.10142 
$\begin{array}{ccccccccccccccc}R & \text { U } & \text { S } & \text { S } & \text { I } & \text { E } & & \text { A } & \text { N } & \text { C } & \text { I } & \text { E } & \text { N } & \text { N } & \text { E } \\ & \text { E } & \text { T } & & \text { I } & \text { M } & \text { P } & \text { E } & \text { R } & \text { I } & \text { A } & \text { L } & \text { E } & & \end{array}$

\section{Steven $S A B O L$}

\section{The Touch of Civilization}

\section{Comparing American and Russian Internal Colonization}

Boulder, CO : University Press of Colorado, 2017, 328 p.

This ambitious comparative study brings together two historiographies that only occasionally touch, despite some obvious affinities. Donald Treadgold, Thomas Barrett and Willard Sunderland have all made innovative use of the historiography of American expansion to gain a better understanding of Russian imperialism. ${ }^{1}$ Perhaps only Peter Kolchin's study of American slavery and Russian serfdom offers a fully-fledged comparison of the kind Sabol is attempting here (he cites Kolchin's work as an inspiration). ${ }^{2}$ Sabol's focus is on the colonization of two peoples - the Sioux in North America and the Kazakhs in Central Asia-by, respectively, the American Republic and the Russian Empire. For Sabol, as for others, the key point which makes the comparison work is that both Russia and the American colonies expanded into contiguous lands to forge a continental empire, informed by the ideologies of European maritime colonialism but nevertheless distinct from it. He refers to this as "Internal Colonization," although his use of the term is not entirely satisfactory. This is partly because in both the Russian and the American case it obscures the campaigns of conquest and expansion which made such colonization possible: these were very far from internal-they were aggressive external projections of power, as Sabol himself makes very clear. There is also a school of thought which defines "Internal Colonization" as the subjection of a people by their own state, and views the oppression of the Russians themselves by the Tsarist regime as comparable to the colonization of other peoples by the Russians. This is obviously far less applicable to the American case, where there was a clear distinction between the political rights accorded to white citizens and those given (or more usually denied) to those of colour, and in particular native Americans. It would have been interesting to see Sabol engage comparatively with this understanding of Russia's "internal colonization," even if he disagreed with it (as this reviewer does), but strangely he does not cite Alexander Etkind, who is probably the most influential advocate of this view. ${ }^{3}$ This uneven acquaintance with recent historiography is visible throughout the book - there is also no reference anywhere to the seminal work of Allen Frank on religion among the Kazakhs. ${ }^{4}$

The book is organised into six chapters, the first of which frames the overall comparison with an account of the evolution of the Sioux and the Kazakhs as peoples, their commonalities and divergences. The most notable difference is that the Sioux became a "horse people" only after the arrival of Europeans, in the seventeenth century, and used their newfound mobility as hunters rather than as pastoralists. Partly as a consequence of this, the Sioux were also far less numerous than the Kazakhs, numbering just 40,000 at the beginning of the $19^{\text {th }}$ century, 
when the Kazakh population was probably over four million. There are also some interesting parallels, in particular the fact that "Sioux" seems to have been a name attached to a confederation of different kinship groups rather than a single tribe, in a very similar manner to the emergence of the Kazakhs as a rebellious offshoot of the Uzbek confederation in the mid- $15^{\text {th }}$ century. In describing the latter Sabol makes an extraordinary error for someone specialising in Kazakh history, when he writes that "The Kazakhs emerged [...] when the 'dissident' Uzbek-Kazakhs migrated north of the Syr-Darya [...] and followed two brothers named Kirei and Zhanibek (who identified themselves as the 'rulers' of the Kazakhs) to become the nomadic pastoralists" (p. 40-41). Sabol does not appear to realise that at this date the Uzbeks were a nomadic tribal confederation based in the northern steppe and western Siberia, with their centre near modern-day Tiumen. As described in the Ta'rikh-i Rashidi, Kirei and Zhanibek led their followers (who were, of course, already nomadic pastoralists) south from this region to the Chu Valley in Semirech'e. ${ }^{5}$ Only at the beginning of the $16^{\text {th }}$ century did the remaining Uzbeks, led by Muhammad Shaybani Khan, conquer the settled region of Mawara' al-nahr and drive out its Timurid rulers, gradually becoming sedentary themselves (though many of the Uzbek tribal elites remained semi-nomadic until the $19^{\text {th }}$ century). Sabol seems to have been confused by the contemporary geography of Central Asia, where the Uzbeks are now to be found to the south of the Kazakhs.

Subsequent chapters explore European expansion into Kazakh and Sioux lands before the nineteenth century, armed conquest and resistance, representations of these nomads by the colonising culture, the European "civilising mission" (which is what Sabol calls "Internal Colonization") and cases of assimilation and blurred identity amongst Kazakhs and Sioux. Sabol's comparisons offer some striking insights, none more so than when he explains the difference between the treaties negotiated between the French and the Sioux and those between the Russians and the Kazakhs - as he explains, the former "was a commercial alliance, not the surrender of political and territorial sovereignty, which is precisely how the Russians interpreted Abul'Khayr's oath." (p. 82). This is a good instance of how comparison really sharpens our understanding of two distinct modes of colonization, one where expansion is driven by trade and settlement, and another led by the state and its rigid notions of sovereignty. As Michael Khodarkovsky has shown, the divergence between this and the view of the Kazakhs themselves, which seems to have been that they entered into an alliance with Russia, would be a source of conflict for the rest of the $18^{\text {th }}$ century (this is another work missing from Sabol's bibliography). ${ }^{6}$ At the same time a vagueness about geography recurs - Sabol describes the negotiations between the Russian empire and Abu'l-Khayr Khan of the Junior zhuz taking place along the "Irtysh Line," but both the river Irtysh and its eponymous line of fortifications run through the eastern steppe and Siberia, the territory of the Middle zhuz. The fortifications faced by Abu'l-Khayr were those of the Ural and (later) Orenburg lines. Sabol's comparisons of Sioux and Kazakh resistance to loss of land, resources and mobility in their turn offer some interesting parallels, though he perhaps does not bring out clearly enough the extent to which the Kazakh leader 
Kenesary Qasimov sought not to drive the Russians from the steppe altogether, but to secure their recognition of his status as Khan - there seems to have been no equivalent of the role played by Chingissid elites for the Kazakhs among the Sioux. When discussing what he calls "Internal Colonization" Sabol is surely correct when he notes that the assimilationist pressures placed on the Kazakhs by the Russians in the $19^{\text {th }}$ century were far less intrusive and extreme than those applied to the Sioux and other Native American peoples, but that the loss of land to Russian settlers, which accelerated markedly in the early 1900 s, had a similarly devastating effect. Sabol's final comparison - of the Society of American Indians and the Alash Orda, groups of self-described intellectuals who by the early $20^{\text {th }}$ century claimed to represent their peoples in the face of the pressures of colonialism-seems more forced. The political circumstances in which the two groups operated were vastly different, both for demographic reasons (the Kazakhs were still a majority of the population in most of their historic territory at this date) and because the Alash would end up grappling with the complete political collapse of the Russian empire in war and revolution.

Those familiar with either Sioux or Kazakh history will find little new within their specialism in this book - it is self-avowedly a work of synthesis - but there is no doubt that the comparisons Sabol makes are often apposite and stimulating, and will introduce historians of one empire to the historiography of another. That said, while some errors, omissions and repetitions are inevitable in a work of this scope, there are rather more of them here than can be justified in a book from a university press which presumably went through peer-review.

1 - Donald W. Treadgold, The Great Siberian Migration: Government and Peasant in Resettlement from Emancipation to the First World War (Princeton, NJ: Princeton U.P., 1957); Thomas Barrett, At the Edge of Empire: The Terek Cossacks and the North Caucasus Frontier, 1700-1860 (Boulder, CO: Westview Press, 1999); Willard Sunderland, Taming the Wild Field: Colonization and Empire on the Russian Steppe (Ithaca, NY: Cornell U.P., 2004).

2 - Peter Kolchin, Unfree Labor: American Slavery and Russian Serfdom (Cambridge, MA: Harvard University Press, 1990).

3 - Alexander Etkind, Internal Colonization: Russia's Imperial Experience (Cambridge: Polity Press, 2011).

4 -Allen J. Frank, Muslim Religious Institutions in Imperial Russia: The Islamic World of Novouzensk District and the Kazakh Inner Horde, 1780-1910 (Leiden: Brill, 2001).

5 - Mirza Haidar Dughlat, A History of the Moghuls of Central Asia, being the Ta'rikh-i-Rashidi of Mirza Haydar Muhammad Dughlat, ed. N. Elias, trans. E. Denison Ross (London: Sampson, Marston \& Low, 1895), 82.

6 - Michael Khodarkovsky, Russia's Steppe Frontier: The Making of a Colonial Empire 1500-1800 (Bloomington, IN: Indiana University Press, 2002).

\section{Alexander Morrison}

New College, Oxford 